\title{
The 45th Annual Meeting of the European Society for Blood and Marrow Transplantation: Welcome Address
}

\author{
24-27 March 2019, Frankfurt, Germany
}

C Springer Nature Limited 2019

Modified and published with permission from https://www.ebmt.org/annual-meeting

Sponsorship Statement: Publication of this supplement is sponsored by the European Society for Blood and Marrow Transplantation. All content was reviewed and approved by the EBMT Committee, which held full responsibility for the abstract selections.

Dear friends and colleagues,

On behalf of the EBMT 2019 Organizing Committee and our joint 45th Scientific Committee we look forward to welcoming you to Frankfurt for the 45th EBMT Annual Meeting, which will include the 35th EBMT Nurses Group Meeting, the 18th Data Management Group Meeting, the 13th Patient, Family and Donor Day, the 11th Quality Management Group Meeting, the 8th Cell Therapy Day, the 8th Paediatrics Day, the 4th Pharmacists Day, the 3rd Psy Day, and for the first time, the 1st Transplant Coordinators Day reflecting the EBMT aim to include all involved health care professions in Stem Cell Transplantation and Cellular Therapy at our Annual Meeting.

The Scientific Programme will offer a great selection of cutting-edge educational sessions and workshops addressing the most recent developments in Stem Cell Transplantation and Cellular Therapies. Germany, with more than 40 transplant centers and more than 3000 allogeneic stem cell procedures, is one of the most active countries for Stem Cell Transplantation in Europe. Germany is also known for its Donor Registries, with over 7.5 million volunteer donors providing hematopoietic stem cells all over the world.

We invite you to visit Frankfurt, a vibrant and modern German city near the river Main, known as a center for international finance, hosting the European Central Bank (ECB), a historical city of emperor coronations, the city of Goethe and the Frankfurt School, and a unique collection of 13 museums devoted to different works of art, from classical paintings to modern art.

The conference center is located in the heart of a financial and business district, the exhibition grounds are among the largest and most modern in the world. The convention center can be reached in just 15 min by public transport or taxi from the Frankfurt International Airport. All hotels are within walking distance of the venue.

We are delighted to welcome our friends and participants from all over the world to the EBMT Annual Meeting 2019 in Frankfurt. We hope that the meeting will increase your knowledge and skills, you will find time for networking with new friends and colleagues and, last but not least, to enjoy the German culture.

Nicolaus Kröger - EBMT President

Thomas Klingebiel - Congress Co-President

Peter Bader - Congress Co-President

Evelyn Ullrich - Scientific Chair

Gesine Bug - Local Organizing Committee Chair

John Murray - President of the Nurses Group

Monika Beffart-Gaines - Local Nurses Committee Chair 